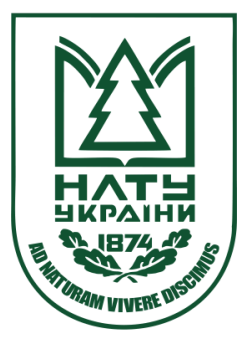

Науковий вісник НлтУ України

Scientific Bulletin of UNFU

ISSN 1994-7836 (print)

https://nv.nltu.edu.ua

https://doi.org/10.36930/40310503

ISSN 2519-2477 (online)

Article received 22.06.2021 p.

Article accepted 25.11.2021 p.

$@ \bigotimes$ Correspondence author

U. O. Bachynska

UDC 630.[228+231]:502.4

medobory.reserve@gmail.com

У. О. Бачинська, Г. І. Баранчук, О. Б. Ходинь

Природний заповідник "Медобори", смт Гримайлів, Украйна

\title{
ДИНАМІКА НАСАДЖЕНЬ ІНТРОДУКОВАНОЇ ЯЛИНИ ЄВРОПЕЙСЬКОЇ (PICEA ABIES (L.) H. КARST.) У ПРИРОДНОМУ ЗАПОВІДНИКУ "МЕДОБОРИ"
}

\begin{abstract}
У природному заповіднику "Медобори" деревостани з участю ялини європейської ростуть на площі 76,6 га (0,9% від вкритих лісовою рослинністю земель). Ці насадження створені до 1990 року. Для кожного класу віку похідних ялинників наведено середньозважені таксаційні показники: вік, діаметр, висота, відносна повнота, клас бонітету, запас. Ялинники в умовах природного заповідника ростуть за першим класом бонітету, однак для них характерні низькі повноти, особливо в старшому віці, що, відповідно, впливає на їх запас. Низька повнота ялинників є наслідком ураження дерев кореневою губкою та опеньком осіннім. Проаналізовано динаміку основних таксаційних показників ялинників на восьми пробних площах. Це високопродуктивні деревостани, першого і вище першого класів бонітету, високоповнотні, зі значними запасами (338$462 \mathrm{~m}^{3} /$ га), тільки деревостан (віком 31 рік) на пробній площі Л-15 за повноти 0,6 має запас 187 м³/га. Показано динаміку всихання і відпаду дерев ялини на пробних площах внаслідок впливу несприятливих погодних умов. Натомість формуються деревостани за типом корінних з аборигенних порід: дуба звичайного (введений штучно), граба звичайного, клена явора, в'яза шорсткого тощо. На двох ділянках утворилися похідні деревостани з переважанням осики, що створює передумови для подальшого розвитку тіньовитривалих порід. На одній пробній площі сформувалося 66-річне насадження з інтродукованим дубом червоним. Природне поновлення наявне на всіх досліджуваних ділянках. Найчисельніше відновлюються клен гостролистий, клен явір, в'яз шорсткий. Самосів та підріст листяних порід наявний у ялинниках усіх вікових груп від початку спостережень. Подано флористичний список рослин та проаналізовано зміни у трав'яному вкритті на пробних площах. Математичному аналізу підлягали компоненти: вік, діаметр, висота, повнота, запас деревостану. За розрахунковим значенням стандартного відхилення та коефіцієнта варіації усі показники мають широкий діапазон розсіювання у досліджених сукупностях.
\end{abstract}

Ключові слова: деревостан; інтродуценти; таксаційна характеристика; типи лісу; природне поновлення; проективне вкриття.

\section{Вступ / Introduction}

На території природного заповідника "Медобори" ліси з участю ялини європейської (Picea abies (L.) H. Karst.) мають штучне походження. Створені вони у не властивих для хвойних порід едафо-кліматичних умовах за межами природного ареалу - у грудових типах лісу на місці вирубаних дубових лісів. У багатих умовах ялина відзначається інтенсивним ростом (річні прирости за висотою можуть сягати 0,8-1,0 м та навіть більше), однак формує рихлу деревину. Наявність таких лісостанів суперечить основному завданню природного заповідника: збереження типових природних комплексів Подільських Товтр - лісостанів широколистяних лісів, з фрагментами степової, лучно-степової та наскельно-степової рослинності. В умовах Західного Поділля ялина сильно пошкоджується кореневими та стовбуровими гнилями та поступово випадає із складу деревостанів [5]. Унаслідок погіршення умов навколишнього середовища за останні десятиріччя відбулося ще більше зниження стійкості ялинових насаджень та всихання на значній площі. На їх місці формуються грабняки, осичники або кленовники тощо.

Об'єкт дослідження - похідні ялинові лісостани на території природного заповідника "Медобори".

Предмет дослідження - методи і засоби встановлення динаміки відпаду ялини звичайної в позаареальних умовах.

Мета роботи - охарактеризувати динамічні природні процеси, які відбуваються у насадженнях з участю ялини європейської, внаслідок зниження їх стійкості.

Для досягнення зазначеної мети визначено такі основні завдання дослідження: дослідити динаміку відпаду дерев та процеси природного відновлення у похідних насадженнях ялини в умовах заповідного режиму на території Західного Поділля.

Наукова новизна отриманих результатів дослідження - вперше для території Західного Поділля досліджено процеси відпаду та природного відновлення у похідних ялинниках за умов заповідного режиму.

Практична значущість результатів дослідження дослідження динаміки відпаду похідних насаджень яли-

Інформація про авторів:

Бачинська Уляна Олександрівна, наук. співробітник. Email: ule156@meta.ua; https://orcid.org/0000-0001-8622-0706

Баранчук Галина Іванівна, наук. співробітник. Email: gaaalkanet@gmail.com; https://orcid.org/0000-0001-7292-9706

Ходинь Орест Борисович, т.в.о. директора. Email: khodun7747@gmail.com; https://orcid.org/0000-0003-3305-266X

Цитування за ДСТУ: Бачинська У. О., Баранчук Г. І., Ходинь О. Б. Динаміка насаджень інтродукованої ялини європейської (Рісеа Abies (L.) H. Karst.) у природному заповіднику "Медобори". Науковий вісник НЛту України. 2021, т. 31, № 5. С. 22-28.

Citation APA: Bachynska, U. O., Baranchuk, G. I., \& Khodin, O. B. (2021). Dynamics of plantations of introduced european spruce (Risea Abies (L.) H. Karst.) in Medobory Nature Reserve. Scientific Bulletin of UNFU, 31(5), 22-28. https://doi.org/10.36930/40310503 
ни звичайної за умов заповідного режиму дає змогу оцінити перспективи вирощування цієї породи у багатих едафічних умовах на території лісогосподарських підприємств Західного Поділля.

Аналіз останніх досліджень та публікацій. Упродовж останніх років проблему всихання ялинників висвітлено у багатьох наукових публікаціях, де проаналізовано причини та особливості всихання ялинників, масштаби патологічних процесів у насадженнях, шляхи підвищення їх біологічної стійкості $[9,14,16,22]$.

У наукових публікаціях щодо насаджень 3 участю ялини європейської в природному заповіднику "Медобори" наголошено, що присутність інтродуцентів (зокрема ялини європейської) в лісах заповідника може виявитися істотним чинником нестабільності лісостану і призвести до зміни порід. Створені штучним шляхом насадження з перевагою хвойних порід не відповідають умовам місцезростання території заповідника. Це призводить до погіршення стану насаджень, до проявлення процесів деградації, а часто і до відмирання деревостанів $[1,8,15]$.

Матеріали та методи досліджсення. Спостереження за станом насаджень 3 участю ялини європейської в умовах природного заповідника "Медобори" здійснюють 31998 р. на восьми постійних лісівничих пробних площах, закладених за стандартною методикою [6]. У деревостанах, де на період закладання домінувала ялина європейська, визначали таксаційні показники, проводили обліки самосіву та підросту, описували трав'яне вкриття. Для досліджень в польових умовах застосовували загальноприйняті в лісівництві методи безпосередніх спостережень. Таксаційні параметри деревостанів визначали за стандартними таксаційними таблицями [12, 13, 19, 23]. Отримані матеріали польових досліджень опрацьовували за допомогою програм Microsoft Excel.

На пробних площах проведено суцільний перелік усіх дерев. Заміри діаметрів здійснювали на висоті 1,3 м мірною вилкою 3 точністю до сантиметра, висоти визначали для кожного ступеня товщини висотомірами B-3 та TruPulse 200 L до дециметра. Для визначення процесів природного поновлення по діагоналі пробних площ закладено облікові ділянки розміром $2 \times 2$ м, на яких обліковується видовий склад підросту і його вік. Успішність природного поновлення визначали за методикою М. М. Горшеніна [7]. Описи проективного вкрит- тя травостою проводили за загальноприйнятою методикою [22]. Періодичність досліджень на пробних площах - п'ять років.

Для статистичного опрацювання використано таксаційні показники восьми пробних площ, закладених у насадженнях 3 ялиною європейською та відомості поквартальних підсумків Таксаційного опису природного заповідника "Медобори", що характеризує насадження з участю ялини європейської. Загальний обсяг вибірки становить 160 виділів загальною площею 76,6 га. Аналізували такі таксаційні характеристики досліджуваних деревостанів: вік насадження (A), діаметр ялини (D), висота ялини $(\mathrm{H})$, відносна повнота $(\mathrm{P})$, запас на 1 га (M), бонітет (В), тип лісорослинних умов та склад насадження.

\section{Результати дослідження та їх обговорення / Research results and their discussion}

В умовах природного заповідника "Медобори" лісостани хвойних порід мають штучне походження. Посаджені вони до створення заповідника у невластивих для ялини європейської умовах - грудах на місці вирубаних дубових лісів. У молодому віці цей інтродуцент росте значно швидше, ніж місцеві види: дуб звичайний (Quercus robur L.), бук лісовий (Fagus sylvatica L.) та їх супутники: ясен звичайний (Fraxinus excelsior L.), клен гостролистий (Acer platanoides L.), клен явір (Acer pseudoplatanus L.) та інші. На час створення природного заповідника площа ялинників перевищувала 350 га, з них близько 300 га займали молодняки I та II класів віку [2]. На сьогодні лісостани з участю ялини європейської ростуть на площі 76,6 га, що становить 0,9 \% від вкритих лісовою рослинністю земель. Серед них переважають деревостани V та VI класів віку (табл. 1).

Розвиток ялини за межею ареалу супроводжується істотним погіршенням санітарного стану після 40-50 років. У середньовікових ялинових лісостанах проявляється масове ураження дерев кореневими гнилями, збудниками яких є коренева губка (Heterobasidion annosum S. L.) та опеньок осінній (Armillaria mellea S. L.) [21]. На 2020 рік площа діючих осередків кореневих гнилей у насадженнях з участю ялини європейської сягала 66,0 га (86,2 \% від площі наявних лісостанів 3 перевагою у складі ялини).

Табл. 1. Таксаційна характеристика насаджень з участю ялини європейської у природному заповіднику "Медобори" / The estimated features of stands that include Norway spruce in Medobory Nature Reserve

\begin{tabular}{|c|c|c|c|c|c|c|c|}
\hline \multirow{2}{*}{ Клас віку } & \multirow{2}{*}{ Площа, га } & \multicolumn{6}{|c|}{ Середньозважені таксаційні показники } \\
\hline & & Вік, роки & Діаметр, см & Висота, м & Відносна повнота & Клас бонітету & Запас, $\mathrm{m}^{3} /$ га \\
\hline II & 2,5 & 16 & 6,0 & 4,5 & 0,78 & I & 28 \\
\hline IV & 7,2 & 35 & 15,8 & 15,8 & 0,83 & I & 226 \\
\hline $\mathrm{V}$ & 17,4 & 47 & 19,4 & 17,3 & 0,68 & I & 185 \\
\hline VI & 35,7 & 57 & 27,3 & 24,9 & 0,69 & $\mathrm{I}^{\mathrm{a}}$ & 291 \\
\hline VII & 6,9 & 64 & 28,0 & 25,0 & 0,59 & $\mathrm{I}^{\mathrm{a}}$ & 253 \\
\hline VIII & 5,0 & 76 & 29,0 & 25,5 & 0,49 & I & 251 \\
\hline IX & 1,4 & 85 & 29,3 & 25,7 & 0,34 & $\mathrm{I}$ & 243 \\
\hline $\mathrm{X}$ & 0,5 & 93 & 37,3 & 28,7 & 0,46 & I & 252 \\
\hline
\end{tabular}

Вивчення динаміки росту, перебігу природних процесів та відпаду ялини європейської проводили на восьми постійних лісівничих пробних площах (позначених Л-12 - Л-19). За умовами місцезростання до свіжих грабових дібров належать ділянки на Л-12, Л-15, Л-16, Л19, а до вологих - Л-13, Л-14, Л-17, Л-18. На час закладання чисті насадження для II класу віку ялини євро- пейської були тільки на Л-15 та Л-16. Пробну площу Л17 закладено в 11-річних лісових культурах, створених зі схемою змішування $1 \times 1$ чергуванням рядів дуба звичайного та ялини європейської. На Л-12 та Л-13 у домішці були граб звичайний (Carpinus betulus L.), в'яз шорсткий (Ulmus glabra Huds.), клен гостролистий природного походження. Пробні площі Л-18 та Л-19 закла- 
дені в лісових культурах ялини з дубом звичайним, а Л14 -3 інтродукованим дубом червоним (Quercus rubra L.). Динаміка таксаційних показників насаджень на пробних площах різниться залежно від віку, повноти в межах різних типів лісів (табл. 2). Для насаджень характерна висока продуктивність, ростуть за першим і вище першого класами бонітету, попри всихання і відпад ялини, високоповнотні, зі значними запасами (338-462 $\mathrm{m}^{3} /$ га), і тільки на Л-15 (насадження віком 31 рік станом на 2018 рік) за повноти 0,6 запас деревостану становить $187 \mathrm{~m}^{3} /$ га.

За результатами досліджень на пробних площах встановлено, що ялинові насадження в умовах заповідника мають низьку життєздатність. За останні десять років відбулося значне погіршення санітарного стану ялини аж до їі масового всихання і відпаду. Найбіль- ший відпад (77 і 74 \%) дерев ялини європейської відбувся на лісівничих пробних площах Л-15 та Л-16 (на час закладання чисті ялинові культури віком 11 та 14 років відповідно) в умовах місцезростання $\mathrm{D}_{2}$ ГД, де після створення заповідника природоохоронні заходи не здійснювали. Унаслідок цього утворилися похідні деревостани природного походження з переважанням у їх складі осики (Populus tremula L.), граба звичайного, в'яза шорсткого. Дещо інша ситуація на пробній площі Л17, закладеній в 11-річних культурах, створених чергуванням рядів дуба звичайного та ялини європейської, де після відпаду 52 \% останньої, сформувався ялиновояворово-грабово-дубовий деревостан. Імовірно, що ялина і надалі буде відпадати, і з часом може сформуватися похідний грабово-яворовий дубняк, що більш-менш відповідатиме корінному типу деревостану заповідника.

Табл. 2. Динаміка таксаційних показників на лісівничих пробних площах у насадженнях з участю ялини європейської / The dynamics of estimated features in the forest trial areas of plantings that include Norway spruce

\begin{tabular}{|c|c|c|c|c|c|c|c|c|}
\hline $\begin{array}{c}\text { Пробна } \\
\text { площа }\end{array}$ & \begin{tabular}{|c|}
$\begin{array}{c}\text { Площа, } \\
\text { га }\end{array}$ \\
\end{tabular} & \begin{tabular}{|l|} 
Вік, \\
роки
\end{tabular} & Склад деревостану & $\begin{array}{c}\text { Запас, } \\
\text { м³ }^{3} \text { a }\end{array}$ & $\begin{array}{c}\text { Відносна } \\
\text { повнота }\end{array}$ & $\begin{array}{c}\text { Клас бо- } \\
\text { нітету }\end{array}$ & $\begin{array}{c}\text { Діаметр } \\
\text { ялини, см }\end{array}$ & $\begin{array}{c}\text { Висота } \\
\text { ялини, м }\end{array}$ \\
\hline \multirow[t]{5}{*}{ Л-12 } & \begin{tabular}{|l|}
0,4 \\
\end{tabular} & 37 & 4Гз4Ялє1Взш1Клг+Дз+Чш од. Лпд & 222 & 0,8 & $\mathrm{I}$ & 21,2 & 18,9 \\
\hline & & 42 & 5Гз3Ялє1Взш1Клг+Дз+Чш од. Лпд, & 252 & 0,8 & $\mathrm{I}$ & 23,8 & 19,4 \\
\hline & & 47 & 5Гз3Ялє1Взш1Яв+Дз+Чш+Лпд од. Клг & 286 & 0,9 & $\mathrm{I}$ & 24,9 & 20,5 \\
\hline & & 52 & 5Гз2Ялє2В3ш1Яв+Дз+Чш+Лпд+Клг & 320 & 1,0 & $\mathrm{I}$ & 25,6 & 21,1 \\
\hline & & 57 & 7Гз1Яв1Ялє1Взш+Дз+Чш+Лпд+Клг & 370 & 0,9 & $\mathrm{I}$ & 28,8 & 22,1 \\
\hline \multirow[t]{5}{*}{ Л-13 } & 0,3 & 56 & 6Ялє2Гз1Взш1Клг+Дз+Чш од. Яв, Яз & 297 & 0,6 & I & 24,7 & 21,0 \\
\hline & & 61 & 6Ялє2Гз1Взш1Клг+Дз+Чш од. Яв, Яз & 333 & 0,7 & I & 28,0 & 22,0 \\
\hline & & 66 & 6Ялє2Гз1Взш1Клг+Дз+Чш од. Яв & 369 & 0,8 & $\mathrm{I}$ & 28,5 & 22,8 \\
\hline & & 71 & 5Ялє3Гз1Взш1Клг+Дз+Чш+Яв & 410 & 0,8 & $\mathrm{I}$ & 30,2 & 23,5 \\
\hline & & 76 & 6Гз2Клг1Яв1Дз+Чш+Взш+Ялє (сух) & 462 & 0,8 & $\mathrm{I}$ & 32,0 & 23,0 \\
\hline \multirow[t]{5}{*}{ Л-14 } & 0,4 & 46 & 5Ялє3Дч2Дз од. Врб, Ос, Гз, Яз, Клг & 225 & 0,7 & $\mathrm{I}$ & 20,6 & 18,8 \\
\hline & & 51 & 5Ялє3Дч2Дз од. Ос, Гз, Яв, Взш, Яз, Клг & 283 & 0,8 & $\mathrm{I}$ & 24,5 & 20,7 \\
\hline & & 56 & 5Ялє3Дч2Дз од. Ос, Гз, Яв, Взш, Яз, Клг & 335 & 0,7 & $\mathrm{I}$ & 26,6 & 21,1 \\
\hline & & 61 & 4Ялє4Дч2Дз од. Ос, Гз, Яв, Взш, Клг & 389 & 0,8 & $\mathrm{I}$ & 28,2 & 21,9 \\
\hline & & 66 & 4Дч4Дз2Ялє+Гз од. Яв, Взш, Яз, Клг, Ос & 429 & 0,9 & $\mathrm{I}$ & 31,6 & 23,1 \\
\hline \multirow[t]{5}{*}{ Л-15 } & 0,1 & 11 & 9Ялє1Гз+Ос+Яз+Клг+Чш+Бп+Врб+Лпд & 42 & 0,7 & $\mathrm{I}^{\mathrm{a}}$ & 6,9 & 7,5 \\
\hline & & 16 & 7Ялє2Гз1Ос+Яз од. Клг, Чш, Бп, Врб, Лпд & 78 & 0,6 & $\mathrm{I}^{\mathrm{a}}$ & 11,3 & 12,3 \\
\hline & & 21 & 7Ялє2Гз1Ос+Яз од. Бп, Лпд & 124 & 0,6 & $\mathrm{I}^{\mathrm{a}}$ & 13,9 & 16,8 \\
\hline & & 26 & 6Ялє2Гз2Ос +Яз од. БП & 188 & 0,6 & $\mathrm{I}^{\mathrm{a}}$ & 19,0 & 19,7 \\
\hline & & 31 & 5Гз3Ос2Ялє+Яз од. Бп & 187 & 0,6 & $\mathrm{I}^{\mathrm{a}}$ & 19,3 & 19,9 \\
\hline \multirow[t]{5}{*}{ Л-16 } & 0,1 & 14 & 9Ялє1Гз+Ос+Бп+Взш+Яв+Врб & 70 & 1,0 & $\mathrm{I}^{\mathrm{a}}$ & 8,6 & 7,4 \\
\hline & & 19 & 5Ялє5Ос+Бп од. Взш, Яв, Гз, Яз, Лпд & 195 & 1,0 & $\mathrm{I}^{\mathrm{a}}$ & 9,8 & 10,2 \\
\hline & & 24 & 4Ялє5Ос1Бп+Взш од. Яв, Гз, Яз, Лпд & 305 & 1,0 & $\mathrm{I}^{\mathrm{a}}$ & 11,0 & 12,0 \\
\hline & & 29 & 3Ялє6Ос1Бп +Взш од. Яв, Гз, Яз & 419 & 1,0 & $\mathrm{I}^{\mathrm{a}}$ & 14,2 & 14,9 \\
\hline & & 34 & 8Ос1Бп1Взш+Ялє од. Яв, Гз, Яз & 387 & 0,9 & $\mathrm{I}^{\mathrm{C}}$ & 16,9 & 15,2 \\
\hline \multirow[t]{5}{*}{ Л-17 } & 0,2 & 11 & 7Ялє3Дз од. Гз, Взш, Врб, Ос, Чш & 27 & 0,6 & $\mathrm{I}^{\mathrm{c}}$ & 7,0 & 7,1 \\
\hline & & 16 & 7Ялє3Дз од. Гз, Взш, Врб, Ос, Чш & 105 & 0,8 & $\mathrm{I}^{\mathrm{C}}$ & 11,4 & 12,2 \\
\hline & & 21 & 5Ялє3Дз1Яв1Гз од. Яз, Взш, Ос, Лпд, Чш & 182 & 0,8 & $\mathrm{I}^{\mathrm{c}}$ & 14,4 & 14,6 \\
\hline & & 26 & 5Ялє3Дз1Яв1Гз од. Яз, Взш, Ос, Лпд, Чш & 279 & 1,0 & $I^{\mathrm{c}}$ & 8,7 & 17,3 \\
\hline & & 31 & 4Дз3Ялє2Яв1Гз од. Яз, Взш, Ос, Лпд, Чш & 338 & 0,8 & $\mathrm{I}^{\mathrm{b}}$ & 22,4 & 18,1 \\
\hline \multirow[t]{5}{*}{ Л-18 } & 0,2 & 76 & 6Ялє2Яз1Дз1Гз од. Клг, Яв, Чш, Лпд, Бкл & 272 & 0,7 & $\mathrm{I}$ & 35,1 & 25,5 \\
\hline & & 81 & 6Ялє2Яз1Дз1Гз од. Клг, Яв, Лпд, Бкл, Взш & 290 & 0,7 & $\mathrm{I}$ & 37,2 & 26,0 \\
\hline & & 86 & 6Ялє2Яз1Гз1Дз од. Клг, Яв, Лпд, Бкл, Взш & 343 & 0,8 & $\mathrm{I}$ & 39,4 & 26,5 \\
\hline & & 91 & 5Ялє2Яз2Гз1Дз од. Клг, Яв, Лпд, Бкл, Взш & 416 & 0,9 & $\mathrm{I}$ & 43,2 & 27,1 \\
\hline & & 96 & 4Ялє3Яз2Гз1Дз од. Клг, Яв, Лпд, Бкл & 427 & 1,0 & I & 43,7 & 28,1 \\
\hline \multirow[t]{5}{*}{ Л-19 } & 0,5 & 71 & 4Дз3Ялє2Гз1Клг+Яз +Чш од.Взш, Бкл & 218 & 0,5 & $\mathrm{I}$ & 28,7 & 21,8 \\
\hline & & 76 & 5Дз2Ялє2Гз1Клг+Яз+Чш+Бкл од. Взш & 256 & 0,8 & II & 34,3 & 22,2 \\
\hline & & 81 & 5Дз1Ялє2Гз1Яв1Бкл+Взш+Чш+Клг+Яз & 296 & 0,8 & II & 33,4 & 22,5 \\
\hline & & 86 & 5Дз1Ялє2Гз1Яв 1Бкл+Взш+Чш+Клг+Яз & 339 & 0,9 & II & 38,9 & 23,0 \\
\hline & & 91 & 5Дз4Гз1Яв+Клг+Яз+Бкл од. Взш, Чш, Ялє & 366 & 0,9 & II & 39,0 & 23,0 \\
\hline
\end{tabular}

На лісівничих пробних площах, де ростуть середньовікові насадження (Л-12, Л-13, Л-19), спостерігається більш масове всихання і відпад ялини. На місці розладнаного насадження, із супутніх порід, а також 3 підростаючого природного поновлення, формується деревостан з граба звичайного, клена явора, в'яза шорст- кого, клена гостролистого в різних співвідношеннях. На пробній площі Л-14 формується насадження дуба звичайного 3 дубом червоним, який в умовах природного заповідника є небажаним інтродукованим видом.

Найменше відпаду ялини (35\%) виявлено на Л-18 96-річному насаджені ялини з участю ясена звичайного, 
граба звичайного, дуба звичайного, що зростає у вологій грабовій діброві, хоча $35 \%$ ялини тут сухостійні (рисунок).

Статистичний аналіз насаджень 3 участю ялини європейської за основними таксаційними параметрами наведено у табл. 3. Результати оброблення відомостей поквартальних підсумків свідчать про широкий діапазон розсіювання у сукупностях таких таксаційних показників, як діаметр, висота та запас на одиниці площі $(V=$ 34,05-35,8 \%), що пояснюють значною неоднорідністю вікової структури, і тільки розмах варіації показника "повнота" характеризується середнім значенням мінливості ознаки $(V-22,56$ \%). На пробних площах розмах варіації показників "вік" і "діаметр" характеризуються високим значенням мінливості ознаки, решта - середнім.
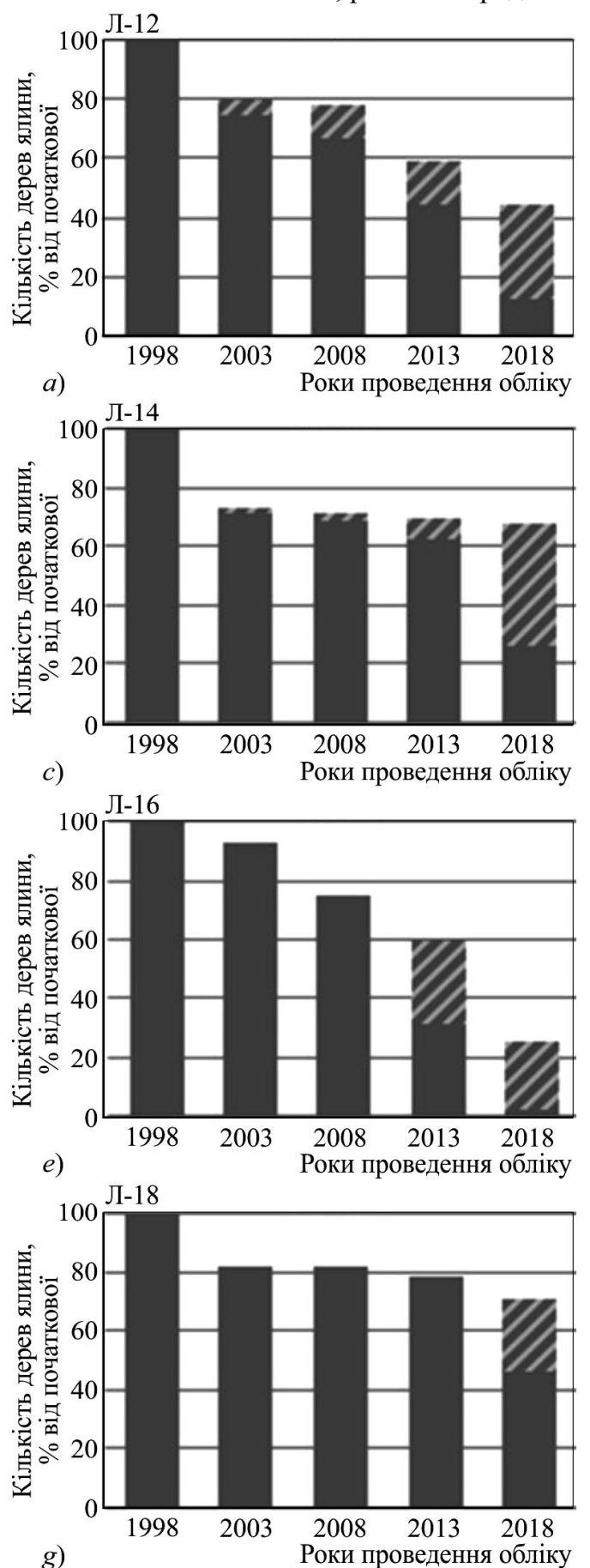

Природне поновлення листяних порід виявили на всіх пробних площах і фіксували в різних кількостях від початку досліджень. Природного поновлення ялини європейської на пробних площах не виявлено. Кількість підросту за шкалою Горшеніна змінюється від 0,04 до 22,2 тис. шт. на 1 га (табл. 4). Найчисельніше майже на всіх пробних площах відновлюються клен гостролистий, клен явір, в'яз шорсткий, ясен звичайний, граб звичайний. Природне поновлення відзначено у всіх вікових групах. Інтродукований дуб червоний добре насівається на Л-14, проте до семирічного віку під наметом деревостану не доживає. Відпад дерев ялини й утворення "вікон" у наметі деревостану сприяють росту підросту і формуванню другого ярусу (Л-13, Л-19).
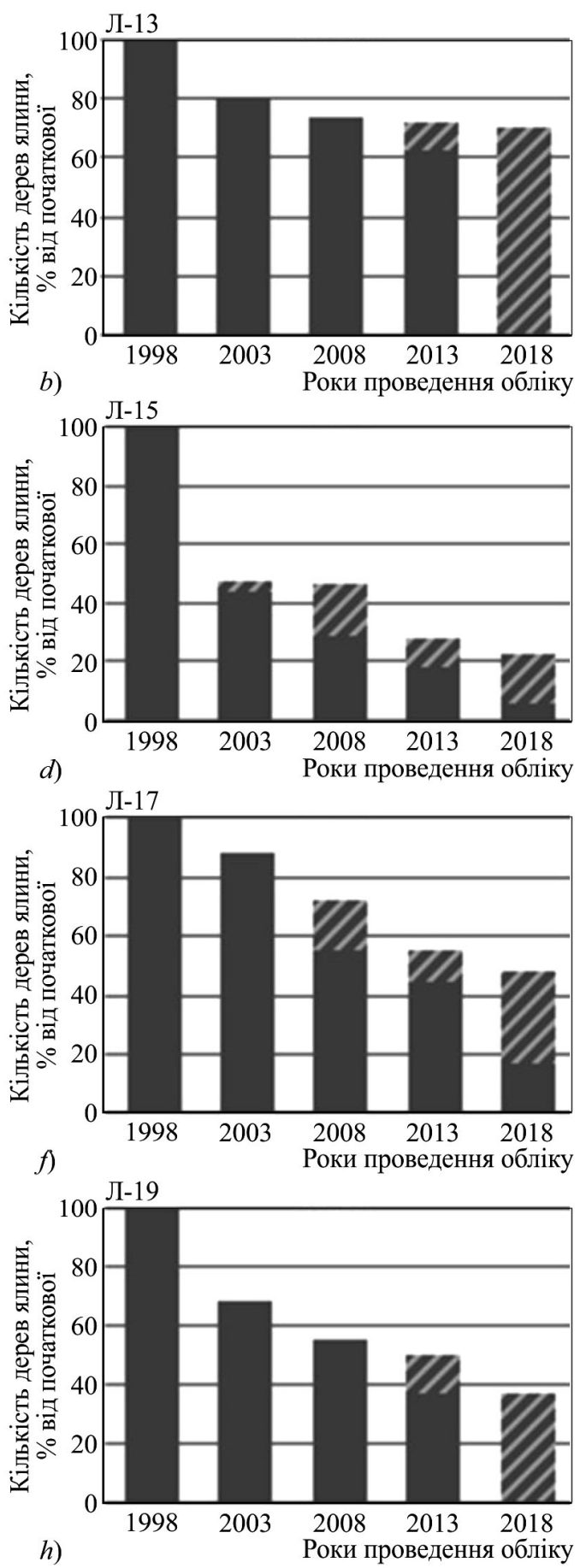

Рисунок. Динаміка відпаду дерев ялини європейської на пробних площах / The dynamics of Norway spruce loss in trial areas in Medobory Nature Reserve 
Табл. 3. Статистична характеристика таксаційних показників насаджень з участю ялини європейської / Statistical characteristic of the estimated features of plantings that include Norway spruce in Medobory Nature Reserve

\begin{tabular}{|c|c|c|c|c|c|c|c|c|}
\hline Показник & $\begin{array}{c}\text { Середне } \\
X_{\text {сер } \pm m} \\
\end{array}$ & $\begin{array}{c}\text { Мінімальне } \\
X_{\min } \\
\end{array}$ & $\begin{array}{c}\text { Максимальне } \\
X_{\max } \\
\end{array}$ & $\sigma^{2}$ & $\begin{array}{c}\text { Стандартне від- } \\
\text { хилення }(\sigma) \\
\end{array}$ & $\begin{array}{c}\text { Коефіцієнт варіації, } \\
V, \%\end{array}$ & $\begin{array}{c}\text { Ексцес, } \\
E \\
\end{array}$ & $\begin{array}{c}\text { Асиметрія, } \\
A \\
\end{array}$ \\
\hline \multicolumn{9}{|c|}{ Природний заповідник } \\
\hline$A$, роки & 53,06 & 14,00 & 97,00 & 361,05 & 19,00 & 35,81 & $-3,00$ & 0,33 \\
\hline повнота & 0,69 & 0,32 & 97,00 & 0,02 & 0,15 & 22,56 & $-0,36$ & $-0,59$ \\
\hline$M, \mathrm{M}^{3} / г \mathrm{a}$ & 260,37 & 14,00 & 0,95 & 11066,7 & 105,20 & 40,40 & $-3,00$ & 0,01 \\
\hline$D$, см & 23,02 & 6,00 & 496,00 & 61,43 & 7,84 & 34,05 & $-0,32$ & 0,06 \\
\hline$H, \mathrm{м}$ & 20,76 & 3,00 & 55,00 & 54,59 & 7,39 & 35,59 & 7,00 & 1,37 \\
\hline \multicolumn{9}{|c|}{ Пробні площі } \\
\hline$A$, роки & 60,25 & 31,00 & 96,00 & 614,44 & 24,79 & 41,14 & $-3,00$ & 0,00 \\
\hline повнота & 0,83 & 0,60 & 462,00 & 0,01 & 0,10 & 12,62 & 0,29 & $-0,94$ \\
\hline$M, \mathrm{~m}^{3} / г \mathrm{a}$ & 370,75 & 187,00 & 0,97 & 6250,94 & 79,06 & 21,33 & 0,94 & $-1,29$ \\
\hline$D, \mathrm{~cm}$ & 29,15 & 16,90 & 43,70 & 76,44 & 8,74 & 29,99 & $-1,12$ & 0,17 \\
\hline$H, \mathrm{M}$ & 21,56 & 15,20 & 28,10 & 13,09 & 3,62 & 16,78 & $-0,35$ & $-0,04$ \\
\hline
\end{tabular}

Табл. 4. Кількісні показники самосіву на лісівничих пробних площах /

The quantitative indicators of self-seeding in the forest trial areas

\begin{tabular}{|c|c|c|c|c|c|c|c|c|c|c|c|}
\hline \multirow{2}{*}{ № 3/п За породами, тис. шт./га } \\
\hline & Дз & Бкл & Клг & Яз & Гз & Яв & Взш & Чш & Клп & Дч & Ос \\
\hline Л-12 & & & 6,3 & 0,8 & 2,1 & 4,7 & 29,5 & 0,2 & & & \\
\hline Л-13 & & & 17,3 & & & 20,6 & 6,4 & 0,3 & & & \\
\hline Л-14 & & & 2,2 & 3,1 & 1,0 & 1,1 & 2,5 & 0,3 & & 17,42 & 1,3 \\
\hline Л-15 & 0,04 & & 0,6 & 5,7 & 2,0 & 0,1 & 0,3 & 0,3 & & 0,04 & 2,1 \\
\hline Л-16 & & 0,2 & 1,1 & 1,1 & & 0,7 & 3,9 & & & & 3,5 \\
\hline Л-17 & 0,23 & 0,2 & 0,6 & 0,2 & 1,1 & 1,0 & 1,5 & & & 0,23 & 0,3 \\
\hline Л-18 & & & 4,5 & 22,2 & 0,2 & 1,4 & 0,6 & & 0,4 & & \\
\hline Л-19 & & 0,4 & 7,4 & 8,6 & 2,9 & 4,8 & & 0,4 & 0,3 & & \\
\hline
\end{tabular}

Підлісок на більшості обстежуваних ділянок рідкий через високу повноту деревостану $(0,7-0,9)$. Його утворюють 3-4 види чагарників, зрідка більше, заввишки 0,3-2,0 м. Домінантом серед підліскових порід є Sambucus nigra L., що фіксується на всіх пробних площах із зімкнутістю на Л-12, Л-14, Л-18, Л-19 до 0,2-0,5, на Л13, Л-15, Л-16, Л-17 одинично або спорадично. Інші види ростуть поодиноко, зокрема: Euоnymus verrucosus Scop. (Л-17, Л-19), Euonymus europaea L. (Л-12-14, 18-19), Corylus avellana L. (Л-12-13, Л-15, Л-19), Viburnum lantana L. (Л-14, Л-16-19), Viburnum opulus L. (Л-19), Swida sanguinea Opiz (Л-14), Crataegus sp.(Л-16-17, Л-19), Grossularia reclinata (L.) Mill. (Л-19), Rosa canina L. (Л-19).

Трав'яне вкриття на обстежених пробних площах $\epsilon$ типовим для Західного Поділля. Загалом на усіх дослідних ділянках з участю ялини (за обстеженнями впродовж останніх 20-ти років) виявлено 78 видів трав'яних рослин (табл. 5). Домінують такі трав'яні види: Asarum europaeum L., Galeobdolon luteum Huds., Galium odoratum (L.) Scop., Aegopodium podagraria L., значно меншу частку вкриття мають Glechoma hirsuta Waldst et Kit., Stellaria holostea L., Stachys sylvatica L., Pulmonaria obscura Dumort. У весняний період масовим видом $\epsilon$ Ficaria verna L., особливо на Л-17, де вкриття ії̈ становить 40-50 \%. Меншу частку мають: Gagea lutea (L.) KerGawl., Anemone nemorosa L., Anemone ranunculoides L. Останній - значно збільшив частку вкриття на Л-13 та Л-18 за останні 10 років.

3 досить великим проективним вкриттям на площах варто відзначити рослини класу Polypodiopsida, чого не спостерігається на інших дослідних ділянках. Вони представлені: Dryopteris filix-mas (L.) Schott. та Dryopteris carthusiana (Vill.) Н. P. Fuchs., які фіксували на всіх пробних площах від одиночних екземплярів до 8-10\%, Athyrium filix-femina L Roth. - на 5-ти площах (Л-12-14, Л-18-19) - від одиночних екземплярів до 10-20\%, Dryopteris austriaca (Jacq.) Woynar. масово спостерігав- ся тільки на Л-14, а на Л-12-13, Л-18 - одиночно. Ще два види, що у заповіднику є дуже рідкісними і траплялися в одному-трьох місцезростаннях, - це Gymnocarpium dryopteris (L.) Newm., що є досить чисельним видом у межах Л-14 (3-5\%), та Polystichum aculeatum (L.) Roth. на Л-12, Л-15 - одиничними екземплярами.

На двох дослідних ділянках у проективному вкритті є Impatiens parviflora DC. - інвазійний вид, що швидкими темпами поширюється у лісових масивах заповідника. Зокрема, на Л-14 у 2006 р. було відзначено декілька рослин, а наступні три п'ятиріччя - 1-2\%, тобто за 15 років не відбулося інтенсивного поширення виду у цьому місцезростанні. А от на Л-19 ситуація з Impatiens parviflora DC. дещо інша. Якщо у 2006 р. було 2-3 \% вкриття, то в період до 2018 р. частка виду зросла до 57 \% (місцями плями до 20-30\%).

Види Червоної книги України [5] на лісівничих пробних площах з участю у деревостанах ялини європейської трапляються не часто, але вони є характерними для широколистяних лісів. Так, Lilium martagon L. фіксували двічі на Л-12 та Л-18 по 1-2 рослини, Listera ovata (L.). Br. - тільки один раз на Л-17, а Epipactis purpurata Smith. виявили на Л-13 одноразово і найчисельніше - 8 генеративних рослин та на Л-15 і Л-17, відповідно, по два рази, 1-3 екземпляри.

3 опрацьованих описів трав'яного вкриття видно, що частка проективного вкриття на більшості пробних ділянок, де відбувається відпад ялини, до 2018 р. зростає або відзначається стабільністю. Зростання відбуваються завдяки таким видам: Galeobdolon luteum Huds., Galium odoratum (L.) Scop., Asarum europaeum L., Glechoma hirsuta Waldst et Kit. Тільки на трьох ділянках (Л-12, Л14 та Л-19), де до 2013 р. спостерігається зростання, а наступні 5 років - спад відсотків, що, ймовірно, пов'язано 3 посушливими періодами 2015-2016 рр., а на Л-14 3 потужною листяною подушкою дуба червоного. 
Табл. 5. Флористичний склад постійних лісівничих пробних площ / The floral composition of the permanent forest trial areas Вид

\begin{tabular}{|c|c|}
\hline \multicolumn{2}{|c|}{ Вид } \\
\hline Actaea spicata $\mathrm{L}$. & Impatiens parviflora $\mathrm{DC}$. \\
\hline Adoxa moschatellina $\mathrm{L}$. & Isopyrum thalictroides L. \\
\hline Aegopodium podagraria $\mathrm{L}$. & Lactuca serriola Torner \\
\hline Ajuga reptans $\mathrm{L}$. & Lamium maculatum (L.) L. \\
\hline Anemone nemorosa L. & Lapsana communis \\
\hline Anemone ranunculoides $\mathrm{L}$. & Lathyrus vernus (L.) Bernh. \\
\hline Anthriscus sylvestris (L.) Hoffm. & *Lilium martagon L. \\
\hline Arctium nemorosum Lej & *Listera ovata (L.). Br. \\
\hline Asarum europaeum L. & Lysimachia nummularia $\mathrm{L}$. \\
\hline Athyrium filix-femina L Roth & Majanthemum bifolium (L.) \\
\hline Carex pilosa Scop. & $\begin{array}{l}\text { Melandrium dioicum (L.) Cass. et } \\
\text { Germ. }\end{array}$ \\
\hline Carex sylvatica Huds. & Millium effusum $\mathrm{L}$. \\
\hline Chaerophyllum sp. & Millium effusum L. \\
\hline Chaerophyllum temulum L. & Moehringia trinervia (L.) Clairv. \\
\hline Chamerion angustifolium $\mathrm{L}$. & Mycelis muralis (L.) Dumort. \\
\hline Chelidonium majus L. & Paris quadrifolia $\mathrm{L}$ \\
\hline Chrysosplenium alternifolium $\mathrm{L}$. & Polygonatum latifolium Desf. \\
\hline Circaea lutetiana $\mathrm{L}$. & Polygonatum multiflorum (L.) All. \\
\hline $\begin{array}{l}\text { Corydalis cava L. Schweigg. et } \\
\text { Koerte }\end{array}$ & Polystichum aculeatum (L.) Roth \\
\hline Corydalis solida (L.) Clairv. & Pulmonaria obscura Dumort. \\
\hline Dactylis polygama Horvat. & Pulmonaria officinalis L. \\
\hline Dryopteris austriaca (Jacq.) Woynar & Ranunculus cassubicus L. \\
\hline Dryopteris carthusiana (Vill.) & Ranunculus repens L. \\
\hline Dryopteris filix-mas (L.) Schott. & Rubus caesius $\mathrm{L}$. \\
\hline *Epipactis purpurata Smith & Rubus idaeus L. \\
\hline Ficaria verna $\mathrm{L}$. & Rumex confertus Willd. \\
\hline Fragaria vesca $\mathrm{L}$. & Salvia glutinosa $\mathrm{L}$. \\
\hline Gagea lutea (L.) Ker-Gawl. & Sanicula europaea L. \\
\hline Galeobdolon luteum Huds. & Scrophularia nodosa L. \\
\hline Galeopsis pubescens Bess. & Stachys sylvatica $\mathrm{L}$. \\
\hline Galeopsis tetrahit L. & Stellaria holostea L. \\
\hline Galium aparine $\mathrm{L}$. & Stenactis anпиа (L.) Nees \\
\hline Galium odoratum (L.) Scop. & Urtica dioica $\mathrm{L}$. \\
\hline Geranium robertianum L. & Veronica chamaedrys L. \\
\hline Geum urbanum L. & Vicia sp. \\
\hline Glechoma hirsuta Waldst et Kit. & Viola mirabilis L. \\
\hline $\begin{array}{l}\text { Gymnocarpium dryopteris (L.) } \\
\text { Newm. }\end{array}$ & Viola odorata $\mathrm{L}$. \\
\hline Hepatica nobilis Mill. & $\begin{array}{l}\text { Viola reichenbachiana Jord. ex } \\
\text { Boreau }\end{array}$ \\
\hline Hypericum perforatum $\mathrm{L}$. & Viola suavis Bieb. \\
\hline
\end{tabular}

Примітка: * види Червоної книги України.

Обговорення результатів досліджсення. На погіршення стану ялинників, які ростуть за межами природних ареалів їх поширення, наголошували неодноразово $[9,16,17]$. Ялина європейська вибаглива до рівномірного зволоження грунту, чутлива до повітряної і грунтової посухи [3]. Тривалі посухи і контрастне зволоження поверхневих шарів грунту призводить до ослаблення та порушення біологічної стійкості ялини. Істотний вплив на погіршення стану рослин та їх біологічної продуктивності мало влаштування осушувально-меліоративних систем у другій половині XX ст., що призвело до штучного пониження рівня підземних вод на 2,5-3,0 м вододільних територій Тернопільщини [20]. У літньоосінній період під впливом високих температур вологість грунту істотно знижується. Це негативно впливає на стан деревостанів ялини європейської.

Порушення стійкості ялинових насаджень на території ПЗ "Медобори" пов'язане зі культивуванням цієї породи поза межами свого природного ареалу та накла- данням тривалих посух з високими максимальними показниками температури повітря, які спостерігалися в літньо-осінні сезони 2011 та 2015-2016 років. Особливо екстремальним був серпень 2015 р., коли максимальні температури повітря майже не опускалися нижче ніж $30{ }^{\circ} \mathrm{C}$, а опадів випало всього 0,2 мм [4].

Процеси природного поновлення в похідних ялинниках відбуваються завдяки типовим для регіону широколистяним породам. Ялина звичайна досить добре поширюється та у своєму ареалі належить до порід-дріад, які забезпечують формування довговічних лісостанів, здатних до саморегуляції [11]. Разом з тим, наші дослідження показують, що похідні ялинники в умовах Західного Поділля не витримують конкуренції із автохтонними деревними породами. Культивування ялини на території лісогосподарських підприємств Західного Поділля, навіть для швидкого отримання деревини, на наш погляд, не має перспектив.

\section{Висновок / Conclusions}

Насадження ялини звичайної на території природного заповідника "Медобори" створені штучно до 1990 р. у свіжих і вологих грабових дібровах. Такі деревостани мають високу продуктивність, ростуть за першим і вище першого бонітетами. Санітарний стан дерев ялини за останні п'ять років істотно погіршився внаслідок значного дефіциту вологи за високих температур. Всихання та відпад дерев ялини виявлено на всіх пробних площах та становило 35-100 \% від їх початкової кількості. На місці ялинників формуються деревостани 3 аборигенних порід: дуба звичайного, граба звичайного, клена явора, в'яза шорсткого, осики. Природне поновлення листяних порід виявлене на всіх досліджуваних ділянках. У його складі переважають клен гостролистий, явір, в'яз шорсткий, що в майбутньому призведе до відновлення деревостанів широколистяних порід.

\section{References}

1. Bondarenko, V. D., Kramarets, V. O., \& Muzyka, M. Ja. (2006). Introducents in the reserve: the problem and possible ways to solve it. Gorgan Biodiversity Conservation and Reproduction. Proceedings of the International Scientific and Practical Conference Dedicated to the 10th Anniversary of the Gorgany Nature Reserve, 16-20. [In Ukrainian].

2. Bondarenko, V. D., Krynytskyi, H. T., Kramarets, V. O., et al. (2006). Strategy and tactics of nature protection activities of the forest reserve (on the example of the nature reserve "Medobory"). Lviv: Spolom. [In Ukrainian].

3. Brodovich, T. M., \& Brodovich, M. M. (1979). Trees and shrubs of the western URSR. Lvov: "Vyshcha shkola". [In Russian].

4. Buhalska, I. I., \& Baranchuk, H. I. (2016). Climatic features of the territory of the nature reserve "Medobory". Dynamics of biologi$\mathrm{cal}$ and landscape diversity of protected areas. Proceedings of the international scientific-practical conference. Kamyanets-Podilskyy: Ruta, 216-220. [In Ukrainian].

5. Didukh, Ya. P. (Ed.). (2009). The Red Book of Ukraine. Flora. Kyiv: Hlobalkonsaltynh. [In Ukrainian].

6. Forest management trial areas. (1983). Bookmark method. OST 56-69-83 from 01.01.1984. Moscow. [In Russian].

7. Horshenyn, N. M., \& Shvydenko, A. Y. (1977). Forestry. Lviv: "Vyshcha shkola". [In Ukrainian].

8. Kramarets, V. A., \& Kryshtalovich, M. V. (1998). Derived stands with the participation of conifers in the Medobory reserve and the possibility of their demute. The state of natural complexes of the Crimean natural reserve and other protected areas of Ukraine, their study and protection: Materials of the scientific-practical 
conference dedicated to the 75th anniversary of the Crimean natural reserve, 56-58. [In Russian].

9. Kramarets, V., \& Matsiakh, I. (2018). The role of biotic factors in spruce decline in the Ukrainian Carpathians. Proceedings of the Forestry Academy of Sciences of Ukraine, 17, 121-132. https://doi.org/10.15421/411827

10. Kramarets, V., Matsyakh, I., Korol, M., Muzyka, M., Yasinovskyi, I., \& Vytseha, R. (2020). Forest stands of the nature reserve "Medobory" in the conditions of the protected regime. Nature of Podillya: study, conservation problems. Proceedings of the scientific-practical conference dedicated to the 30th anniversary of the Medobory Nature Reserve, 185-197. [In Ukrainian].

11. Kramarets, V., Popovich, M., \& Bojko, O. (2019). Influence of Ecological and Biological Features of Tree Species on successions in the Forests Succession in of the Ukrainian Carpathians Proceedings of the Forestry Academy of Sciences of Ukraine, 18, 11-20. https://doi.org/10.15421/411901

12. Marketability. (1969). Tables of growth and marketability of tree plantations of Ukraine. Kyiv: Urozhay. [In Ukrainian].

13. Materials. (1987). Regulatory and reference materials for forest taxation of Ukraine and Moldova. Kyiv: Urozhay. [In Russian].

14. Maurer, V. M., \& Yarema, S. I. (2014). Causes and features of drying of spruce trees of NPP "Synevir" and ways to increase their biological stability. Ukrainian Journal of Forest and Wood Science, 198, 144-149. [In Ukrainian].

15. Muzyka, M. Ya. (2006). Introducers in the forests of the nature reserve, the problem and directions of its solution. Forestry of Ukraine in the context of world trends in forestry development". Proceedings of the International scientific-practical conference dedi- cated to the 150th anniversary of the origins of the Department of Forestry NLTU Ukraine, 283-285. [In Ukrainian].

16. Oliinyk, V. S., \& Zeinalian, A. M. (2020). Altitude features of spruce decline on the north-eastern megaslope of Ukrainian Carpathians. Foresty and Forest Melioration, 136, 19-24. https://doi.org/10.33220/1026-3365.136.2020.19

17. Parpan, V. I., Shparyk, Yu. S., Slobodyan, P. Ya., Parpan, T. V., et. al. (2014). Forest management peculiarities in secondary norway spruce (Picea abies (L.) H. Karst.) stands of the Ukrainian Carpathians. Proceedings of the Forestry Academy of Sciences of Ukraine, 12, 20-29. http://nbuv.gov.ua/UJRN/Nplanu 2014124

18. Serebryakova, T. I. (Ed.). (1976). Plant cenopopulations (basic concepts and structure). Moscow: Nauka. [In Russian].

19. Taxation. (1993). Assortment tables for taxation of young and middle-aged tree stands. Kyiv: USKHA. [In Russian].

20. Tsaryk, L. P., \& Tsaryk, P. L. (2016). Environmental impact of mass land drainage on the territory of Ukraine, Ternopil. Visnik Kamanec-Podilskogo nacionalnogo universitetu imeni Ivana Ogienka. Seria Ekologia, 1, 257-266. http://nbuv.gov.ua/UJRN/Vkpnueko_2016_1_29

21. Tsyliuryk, A. V., \& Shevchenko, S. V. (2008). Forest phytopathology. Kyiv, KVIC. [In Ukrainian].

22. Ustkyi, I. M. (2011). Dynamics of condition of forest stands of the main forest forming tree species in Ukraine in 1990-2006. Scientific and production edition "Forestry journal", 1, 32-35. [In Ukrainian].

23. Vinichenko. (2013). Forest taxation guide. Kyiv: Vinichenko. [In Ukrainian].

U. O. Bachynska, G. I. Baranchuk, O. B. Khodin

Medobory Nature Reserve, Hrymayiliv, Ukraine

\section{DYNAMICS OF PLANTATIONS OF INTRODUCED EUROPEAN SPRUCE (RISEA ABIES (L.) H. KARST.) IN MEDOBORY NATURE RESERVE}

Forests with the participation of European spruce which were planted before 1990 grow on an area of 76.6 hectares in Medobory Nature Reserve ( $0.9 \%$ of the land covered with forest vegetation). In the course of research the distribution of plantations was analysed by age classes with the derivation for each weighted average assessment indicators such as age, diameter, height, relative completeness, quality class, and stock. Plantations are found to grow in the first class of quality, but are characterized by low fullness, especially in old age, which, accordingly, affects the stock. Spruce growing in the reserve is damaged by a root sponge. The dynamics of the main indicators in eight trial areas is analysed. Plantations are characterized by high productivity, grow on the first and above the first quality, despite drying and falling of spruce, high-density, with significant reserves $\left(338-462 \mathrm{~m}^{3} / \mathrm{ha}\right)$, and only thirty one-year old stands with a density of 0.6 have a reserve of $187 \mathrm{~m}^{3} / \mathrm{ha}$. The dynamics of drying and shedding of spruce trees in the trial areas after adverse weather conditions occurring there respectively $60-100 \%$ and $35-77 \%$, is shown. Instead, stands are formed by the type of native aboriginal species such as common oak (introduced artificially), hornbeam, maple, rough elm, etc. Derivative stands with a predominance of aspen were formed in two areas, which created preconditions for the further development of shade-tolerant species. A 66-year-old plantation with introduced red oak, which is not typical for the reserve, was formed in one trial area. Reforestation was recorded in all trial areas. The most restored species are considered to be maple, sycamore maple, rough elm; natural renewal observed from the beginning of observations in all age groups. A floristic list of plants is given and changes in the grass cover in the trial areas are analysed. The following components were subject to mathematical analysis: age, diameter, height, completeness, stock. According to the calculated value of the standard deviation and the coefficient of variation, all indicators have a wide range of scattering in the studied plantations.

Keywords: forest stands; introducers; estimated features; forest types; natural regeneration; projective shelter. 